\title{
MODERN CONSOLIDATION METHODS FOR CATHOLIC CHURCH IN BAROQUE STYLE FROM ARAD FORTRESS, ROMANIA
}

\section{ALEXANDRU C. ION $^{1 *}$ AND MARIUS MOSOARCA $^{2}$}

\author{
${ }^{1}$ The National Institute of Research and Development URBAN INCERC Timisoara \\ Str. Traian Lalescu, nr.2, Zip code 300223, Timisoara, Jud. Timis, Romania \\ e-mail: alexandru.ion86@yahoo.com (*corresponding author) \\ ${ }^{2}$ Polytechnic University of Timisoara, Faculty of Architecture and Urban Planning \\ Str. Treian Lalescu, nr.2A, Zip code 300223, Timisoara, Jud. Timis, Romania \\ e-mail: marius.mosoarca@upt.ro
}

Keywords: masonry, consolidation, church, monument, restoration

\begin{abstract}
This paper presents the results of a study carried on a baroque style Catholic Church, in the field of determining its bearing capacity, restored with reversible materials, technologies and consolidation methods. The Franciscan Monastery is situated in Arad fortress and is an historical building. The structural resistance of the building suffered severe degradation because of the poor maintenance over the years. Two nonlinear analyses were made on the structure that showed that the building may suffer severe structural damage after an earthquake. Based on the results of these analyses some consolidation methods were proposed for the structural elements of the building: walls, arches, vaults, pillars, towers and foundations. Then a third analysis was made using the proposed consolidation methods to determine their efficiency.
\end{abstract}

\section{INTRODUCTION}

Structural consolidation interventions of historical buildings must be reversible and slightly invasive. Because of this it is very difficult to evaluate the efficiency of this sort of punctual interventions on a structure. This paper presents the efficiency of modern and reversible consolidation methods proposed for a baroque style Catholic Church that is an historical building. The study was carried out within the master section entitled "Restoration and Patrimonial Regeneration" within the Faculty of Architecture and Urban Planning at the Polytechnic University of Timisoara.

The historical monument that is the subject of this paper is the Franciscan Monastery from Arad fortress near the city of Arad. The architectural ensemble of Arad fortress is nominated in the list of Historical Monuments of national importance. The fortress is a Vauban type fortification. In the year 1762, the construction of the fortress was ordered by Queen Maria Theresa of Austria. The Franciscan church already existed before the construction of the fortress. The two lateral bodies of the Franciscan Monastery which house the cells of the monks were not built at the same time with the church, but in different stages. During the First and the Second World War and during the communist regime the monastery changed its destination several timesto a prison, stables, bedrooms for the military staff, driving school for soldiers, ammunition deposit. After the year 1989 the Franciscan Monastery was neglected maintenance and has suffered major degradations. 
A bibliographic study was made which contain studies made within the master's degree studies $[1,2]$. Important research in the field was done as basis for the consolidation methods. A. Narita et al. [3] that describes the behavior and damages of historic buildings that are situated in Banat region in Romania, the same geographic zone as the Franciscan Church. M. Mosoarca et al. [4] studies about the failure mechanisms of Roman Catholic churches and Orthodox churches in seismic area of Banat. A comparison between the two types of failure mechanisms of the churches is also made because the two types of churches have different shapes in plan. M.R. Valluzzi et al. [5] discuss the potentials and limitations of composite materials used in strengthening historical buildings. C. Modena et al. [6] that describe criteria and technologies that can be used for the structural repair and strengthening of architectural heritage.

To determine the bearing capacity of the Franciscan Monastery several nonlinear analysis were conducted with the TreMuri program $[7,8]$. In the first analysis the seismic behavior of the individual church was studied. In the second analysis the seismic behavior of the church was studied with the adjacent building bodies forming an aggregate. In the third analysis the seismic behavior of the consolidated individual church was studied.

\section{DESCRIPTION OF THE STRUCTURE AND DEGRADATIONS}

The Franciscan Monastery (Figure 1) is made out of three different buildings (Figure 2): the Church of the Monastery and twe side structures with two floors where the Franciscan

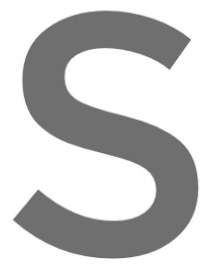
monks had their cells. The bearing structure of the church is ma
are $1.5 \mathrm{~m}$ thick. The foundations of the structure are made out
underneath the structure. The thickness of the walls of the towe
of the church there is a masonry vault that is supported by
unauthorized intervention, and the wall of the main façade. The $30 \mathrm{~cm}$ thick RC pillars. The entire church is covered with masonry vaults. Over the vaults

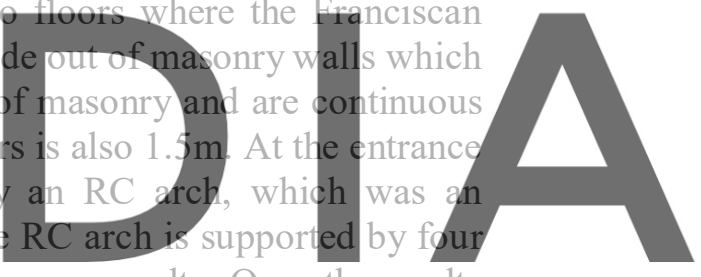

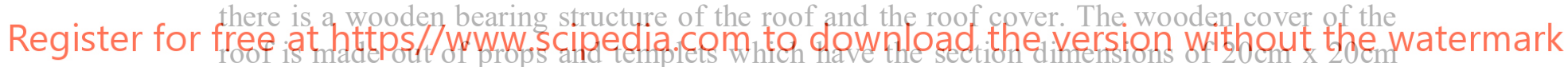
and rafters and braces which have the section dimensions of $15 \mathrm{~cm} \times 17 \mathrm{~cm}$.

The monk cells structure is made out of a thick compartmentalization with bearing masonry walls which are $30 \mathrm{~cm}$ thick on the inside and perimeter walls which are $1 \mathrm{~m}$ thick on the outside. The slabs of the cells are made out of masonry vaults which are $50 \mathrm{~cm}$ thick on both floors. Over the vaults there is the wooden bearing structure of the roof and the cover of the roof. Underneath parts of the structure of the monk cells there is a basement.

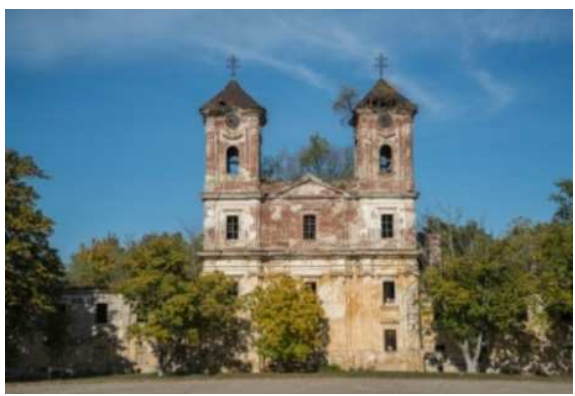

Figure 1: Monastery Façade 


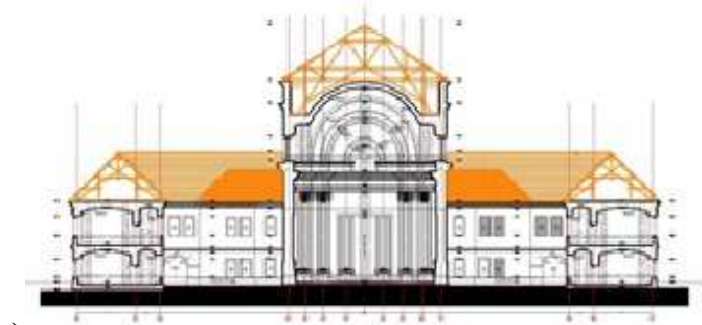

a)

Figure 2: a) Monastery section, b) Monastery plan

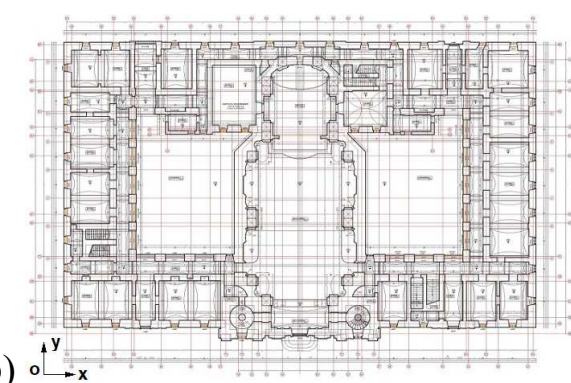

b) $\mathrm{ot}_{\rightarrow-x}^{\mathrm{y}}$

The structural strength of the monastery was severely damaged due to lack of maintenance over time. At the on-site examination of the church observations were made of vertical cracks in vaults and arches (Figure $3 \mathrm{~b}$ ) and inclined cracks at the corners of the buildings which were caused by the subsidence of the foundations. Water infiltration led to the degradation of the masonry, the degradation and the failure of the vaults (Figure 3 a), the peeling of the plaster and the corrosion of concrete and steel bars (Figure $3 \mathrm{c}$ ). Also because of the bad maintenance the framing of the roof and the roof covering are almost completely destroyed allowing water infiltration into the building (Figure $3 \mathrm{~d}$ ) [7].
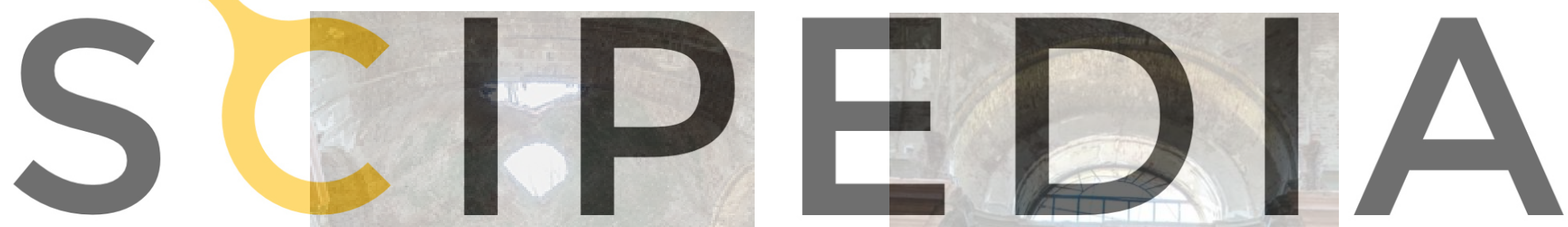

Register for free at https//www.scipedia.com to download the version without the watermark

c)

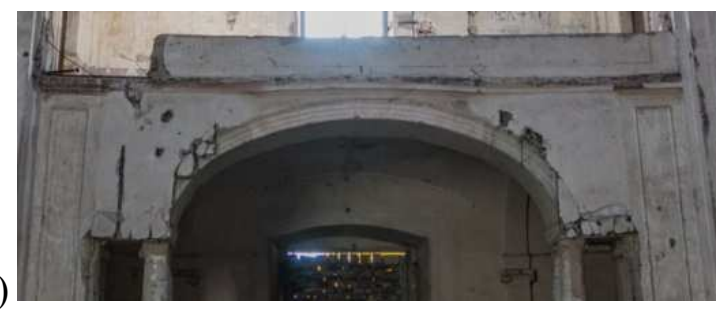

d)

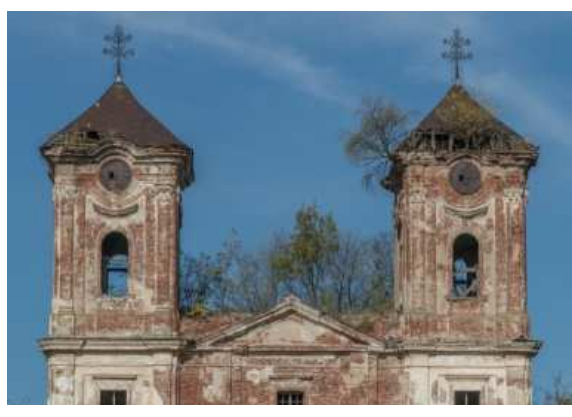

Figure 3: Structural degradation of the church: a) Vault failure, b) Cracked arches, c) Corrosion of the RC arch, d) Roof degradation

Observations were also made of some unauthorized interventions to the structure of the church: two doorway holes on the side walls (Figure 4 a) and the construction of a masonry wall with RC frame to separate the churches apse (Figure 4 b) [7]. 
a)

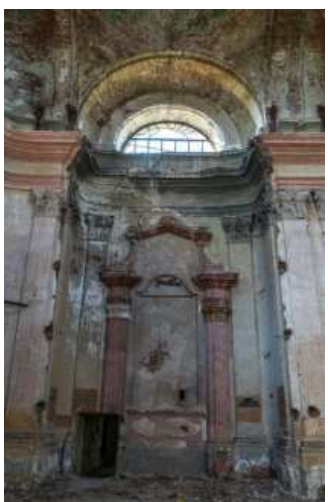

b)

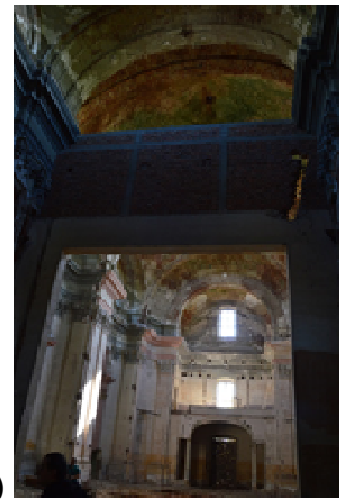

Figure 4: Unauthorized interventions: a) Doorway hole, b) Masonry wall with RC frame

\section{THE DYNAMIC SPATIAL ANALYSIS OF THE UNCONSOLIDATED}

\section{STRUCTURE}

The first step was to realize a push-over analysis of the unconsolidated structure of the church with the help of the TreMuri program to determine the bearing capacity and rigidity of the church. A 3D model of the church is presented in Figure $5[7,8]$
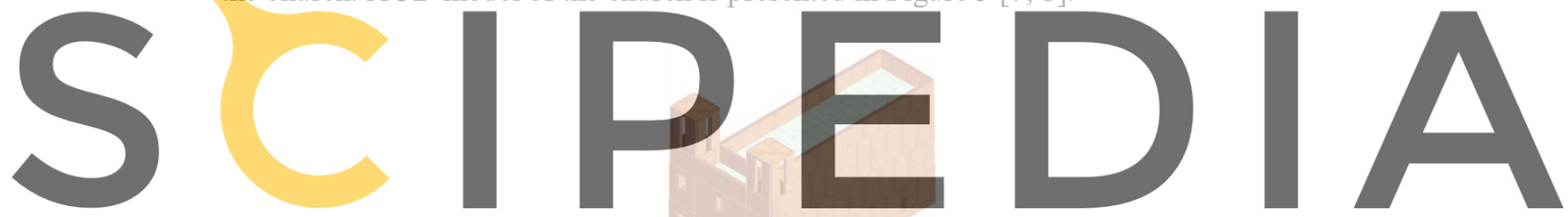

Register for free at https//www.scipedia.com to download the version without the watermark

Figure 5: 3D model of the church

The analysis was created for peak ground acceleration of $0.20 \mathrm{~g}$ according to the Romanian seismic code P100-1/2013. The vibration modes of the structure are shown in Figure 6 . The vibration modes of the structure indicate a predominant solicitation of general torsion.

a)

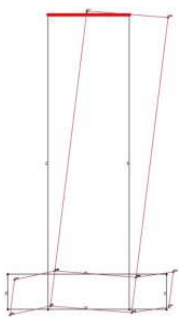

b)

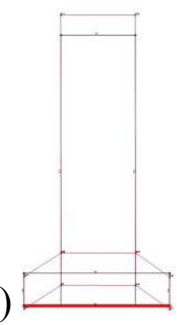

c)

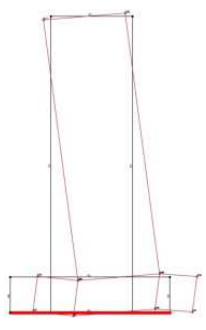

Figure 6: The vibration modes of the structure: a) the first mode: torsion, $\mathrm{Ts}=0.518 \mathrm{sec}, \mathrm{b}$ ) the second mode: translation, $\mathrm{Ts}=0.454 \mathrm{sec}, \mathrm{c}$ ) the third mode: torsion, $\mathrm{Ts}=0.431 \mathrm{sec}$ 
On the Ox axis of the church the maximum horizontal displacement of the tower is $2 \mathrm{~cm}$ and the maximum shear force is $6200 \mathrm{KN}$ as shown in Figure 7.

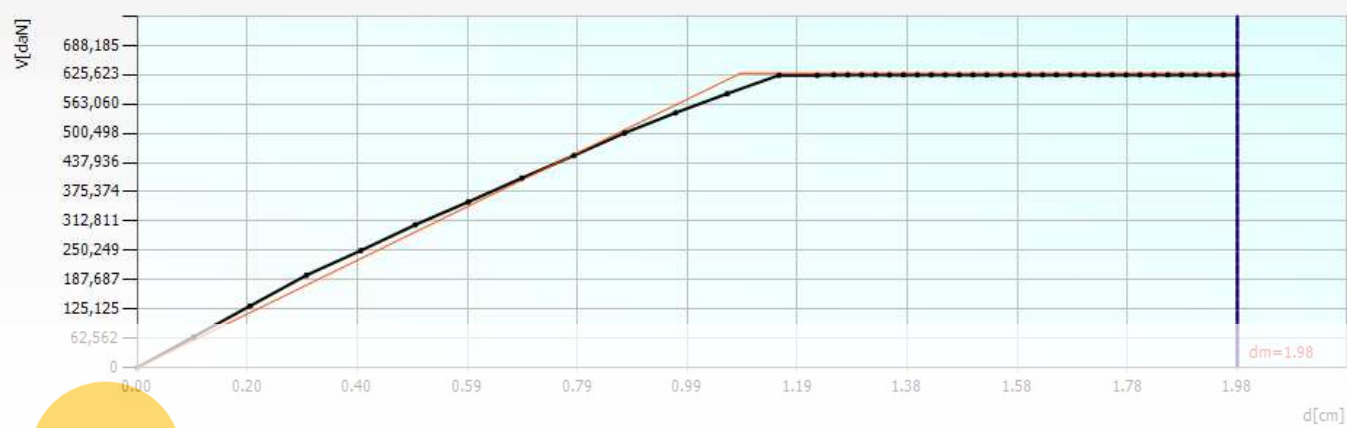

Figure 7: The force-displacement diagram, when the seismic force is applied on the Ox axis

Figure 8 presents the failure mechanisms of the structure on the Ox axis after an earthquake. On the main façade the earthquake produces diagonal cracks in the pears of the tower. On the lateral façade of the church we have diagonal cracks only at the top of the wall
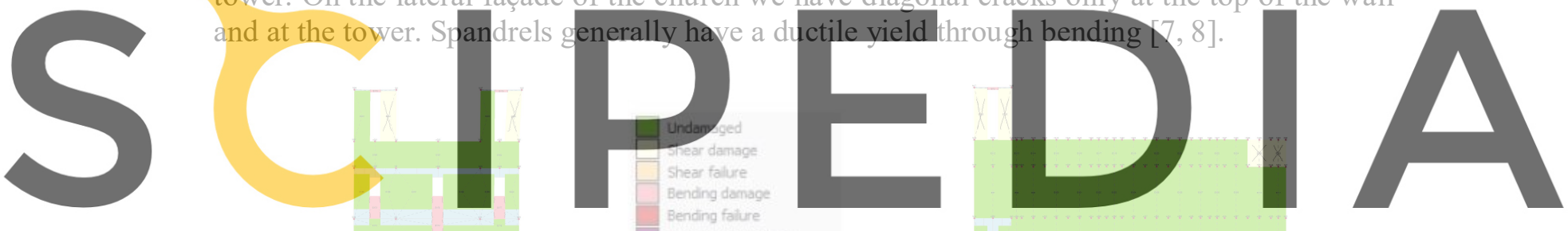

Register for free at https//www.scipedia.com to downloagl the version without the watermark

Figure 8: Failure mechanisms of the structure on the ox axis: a) main façade b) lateral façade

On the Oy axis of the church the maximum horizontal displacement of the tower is $5.7 \mathrm{~cm}$ and the shear force is approximately $4800 \mathrm{KN}$ as shown in Figure 9.

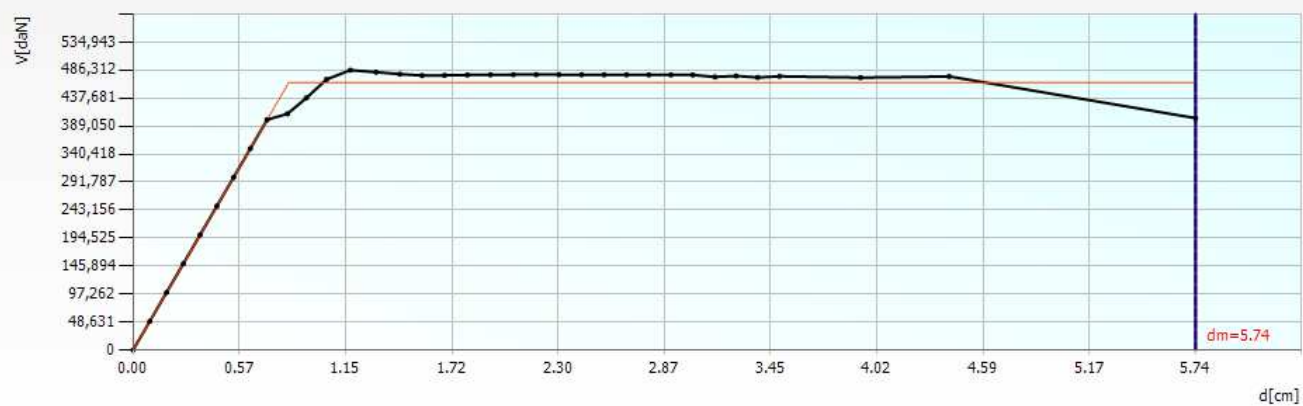

Figure 9: The force-displacement diagram, when the seismic force is applied on the Oy axis 
In Figure 10 there are presented the failure mechanisms of the church on the Oy axis after an earthquake. We can see only ductile yielding on the main façade on the spandrels. On the lateral façade we have brittle yielding on the upper side of the structure.

a)

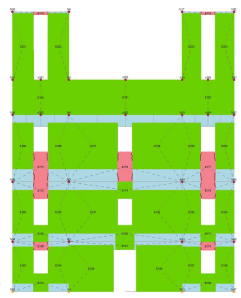

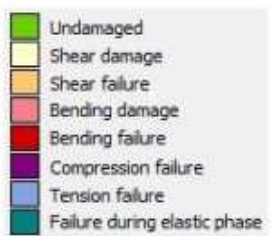

b)

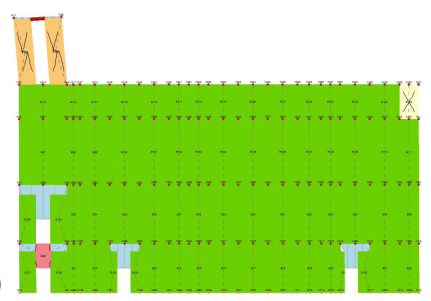

Figure 10: Failure mechanisms of the structure on the Oy axis: a) main façade, b) lateral façade

The second step was to realize another push-over analysis which contains the church in aggregate with the two side buildings that contain the cells of the monks. The 3D model is displayed in Figure 11 [8].
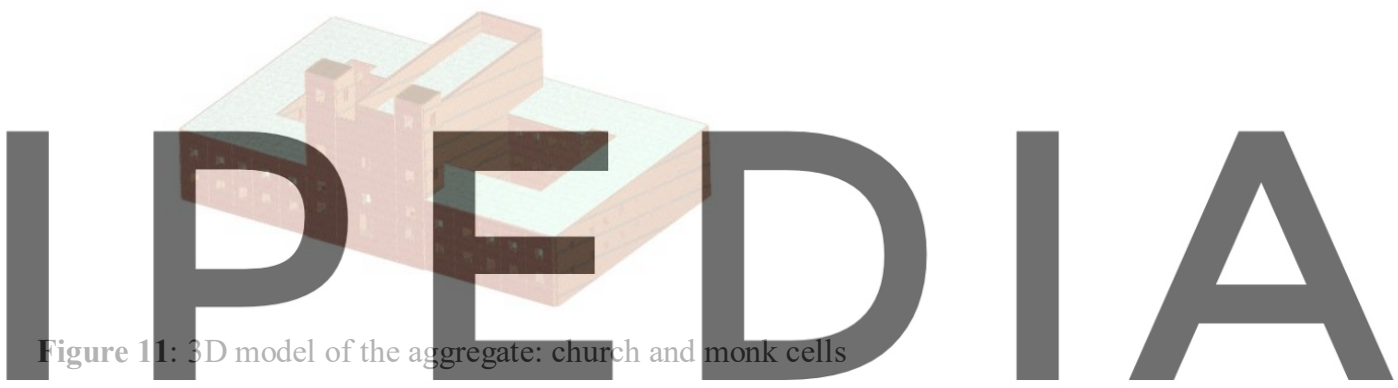

The analysis was made with the same parameters as the analysis where only the church Register for freesatdlettips//www.scipedia.com to download the version without the watermark

On the Ox axis of the monastery (Figure 12), the maximum displacement of the tower is $1.30 \mathrm{~cm}$ and the shear force is $15000 \mathrm{KN}$. Comparatively to the model where the church is modeled alone the maximum displacement decreased from $2 \mathrm{~cm}$ to $1.30 \mathrm{~cm}$ and the total shear force raised from $6200 \mathrm{KN}$ to $15000 \mathrm{KN}$.

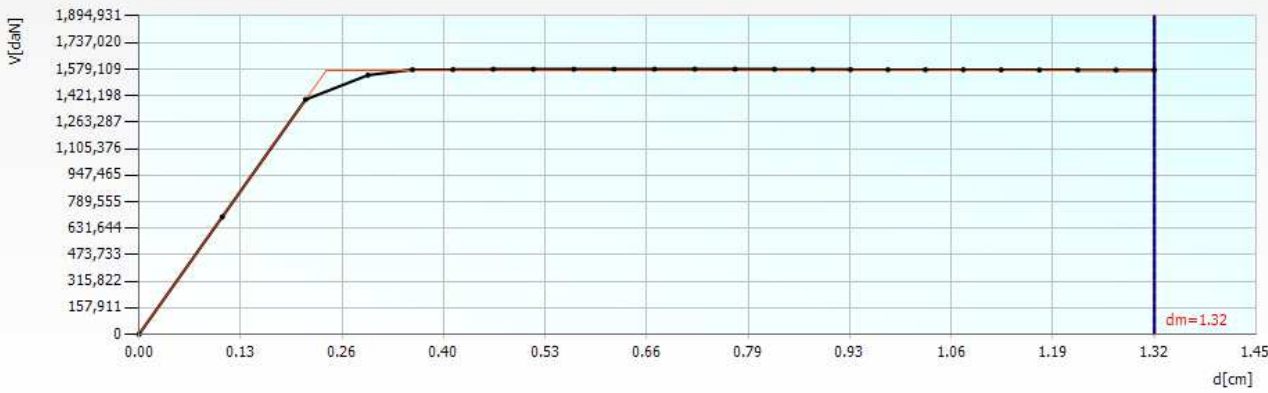

Figure 12: The force-displacement diagram when the seismic force is applied on the Ox axis 
As we can see from Figure 13, there are a lot less failure mechanisms compared to the analysis where just the church was modeled. On the main façade we have ductile yielding on the spandrels, but brittle yielding can only be observed at the towers and two spandrels instead of the entire façade like in the first analysis. On the lateral façade we have failure mechanisms only on the towers.

a)

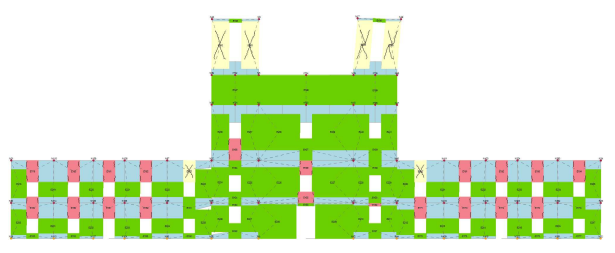

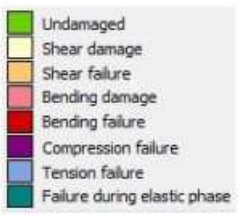

Faliure during elastic phase b)

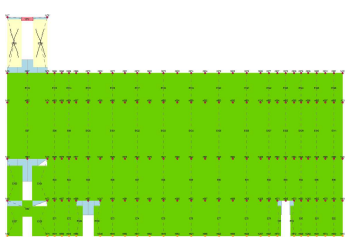

Figure 13: Failure mechanisms on the aggregate structure on Ox axis: a) main façade, b) lateral façade

On the Oy axis of the monastery (Figure 14), the maximum displacement is raised from $5.70 \mathrm{~cm}$ to $5.90 \mathrm{~cm}$ and the shear force is raised from $4800 \mathrm{KN}$ to $18000 \mathrm{KN}$.
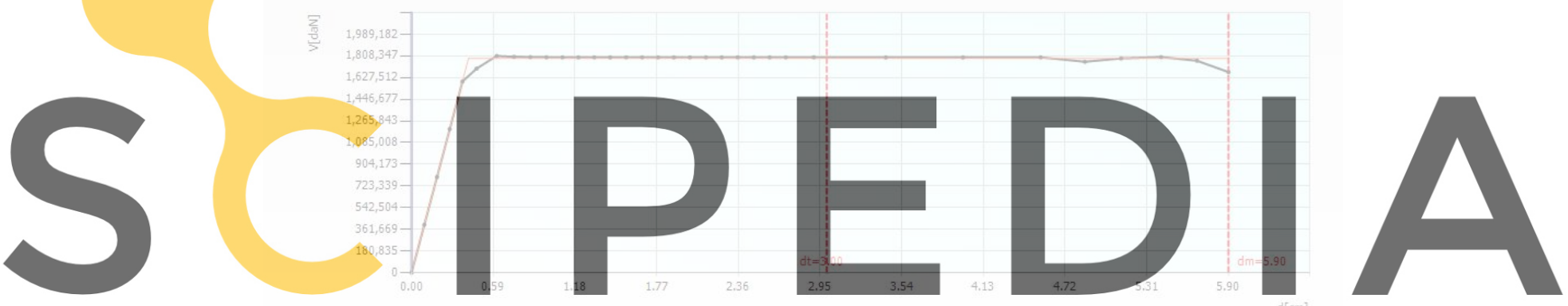

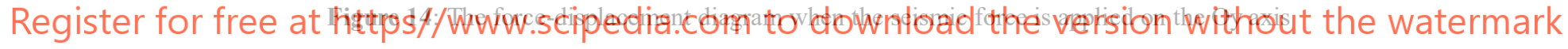

The main façade (Figure 15 a) of the monastery has ductile yielding failure mechanisms on the spandrels similar to the analysis where the church was modeled alone. On the lateral façade (Figure $15 \mathrm{~b}$ ) there is brittle yielding on the tower of the church.

a)

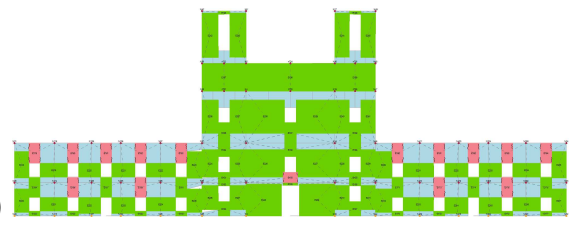

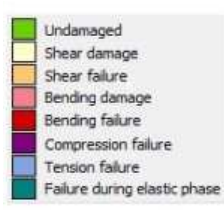

b)

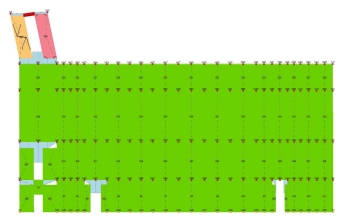

Figure 15: Failure mechanisms of the aggregate structure on Oy axis: a) main façade, b) lateral façade

\section{PROPOSED CONSOLIDATION METHODS}

After the interpretation of the results from the non-linear analysis, consolidation methods were proposed for each of the elements of the bearing structure. In order to maintain the rigidity of the structure and to increase the bearing capacity, minimal interventions were proposed with composite materials which were produced by Kerakoll Company [7, 9]. 
The proposal for the arches (Figure 16 a) was that they would be consolidated on the soffit with galvanized steel fibers Geosteel G 1200, mortar GeoCalce G Antiseismico and Steel DryFix 10 connectors.

a)

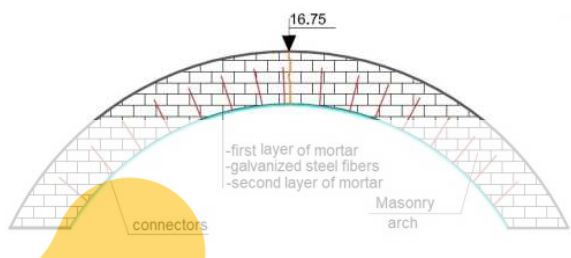

b)

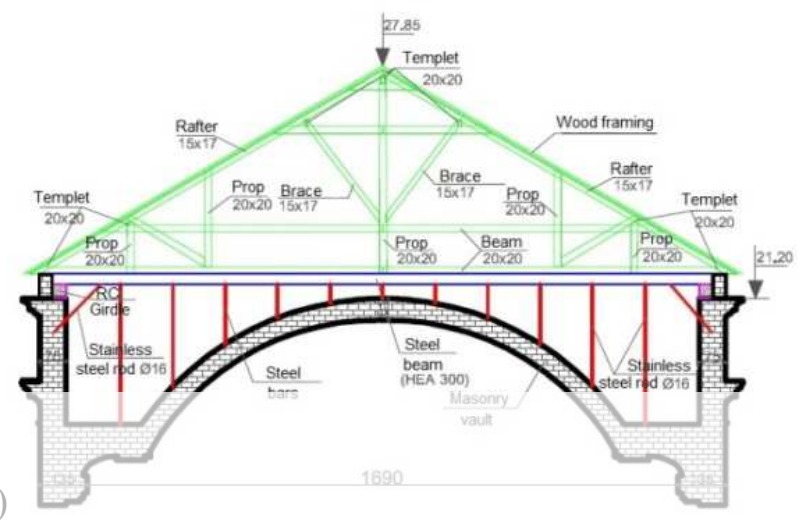

Figure 16: Proposed consolidation methods: a) Consolidation of the arches, b) consolidation of the vaults

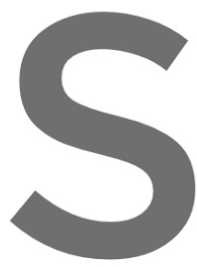

The loads from the transversal vaults of the church will be transferred through vertical steel bars to a proposed network of steel beams which lean on the perimeter structural walls

(Figure 16 b). This network of beams also transfers the loads from the roof to the structural walls $[7,9]$.

The consolidation of the altar walls

with galvanized stee

DryFix 12 connectors fibers

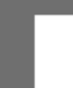

Galvanized stoel not
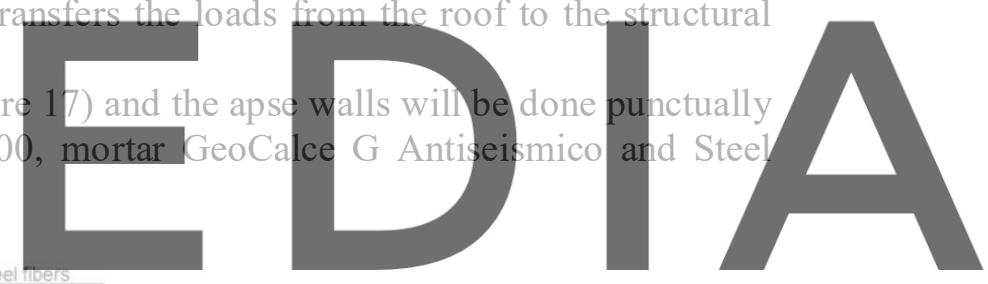

Register for free at https//www.scipedia.com to download the version without the watermark

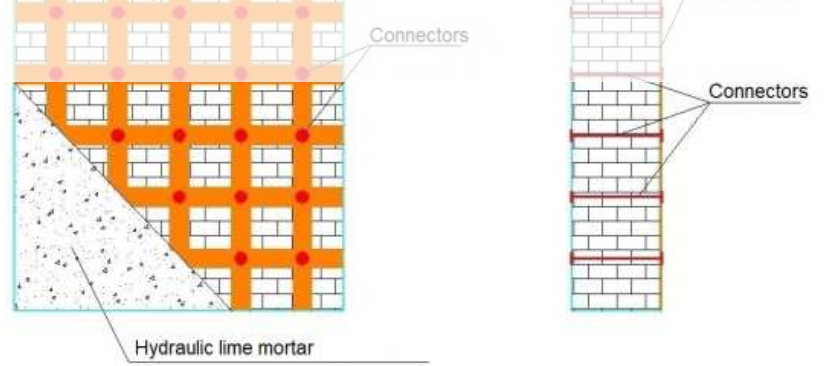

Figure 17: Consolidation of altar walls

For the RC arch and RC pillars (Figure 18) at the entrance of the church, the consolidation with galvanized steel fibers Geosteel G 1200, mortar GeoCalce G Antiseismico and Steel DryFix 12 connectors were chosen. 
a)

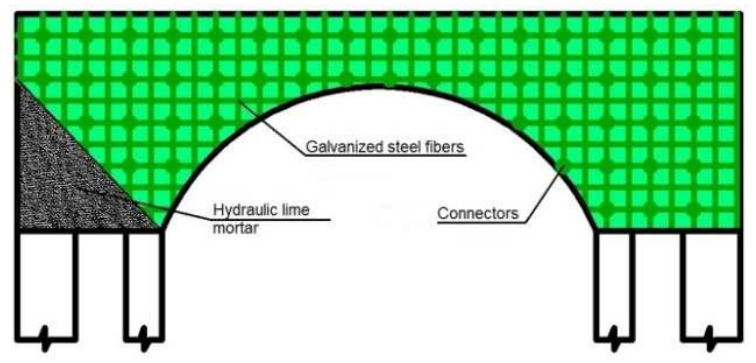

b)

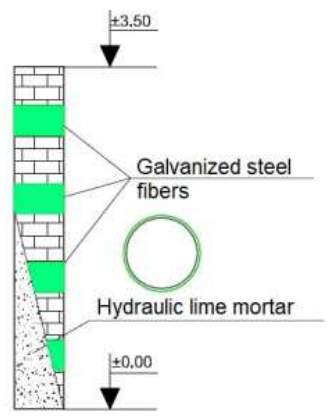

Figure 18: Consolidation of the: a) RC arch, b) RC pillar

The towers of the church (Figure 19 a) will be consolidated on the inside with galvanized steel fibers Geosteel G 1200, mortar GeoCalce G Antiseismico and Steel DryFix 12 connectors.
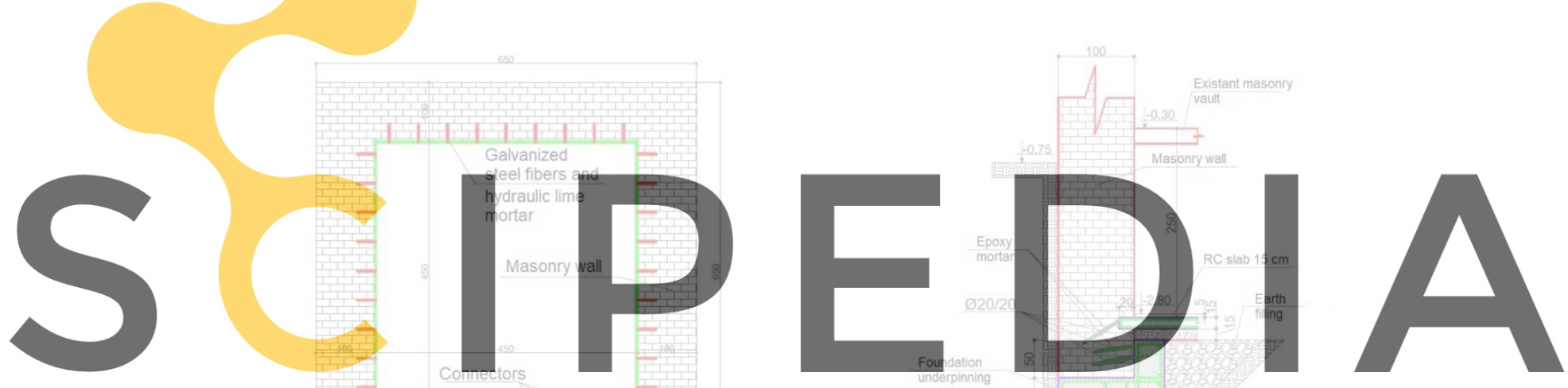

Figure 19: Proposed consolidation methods: a) Consolidation of the tower, b) Consolidation of the foundation

For the foundations an underpinning of the foundation (Figure $19 \mathrm{~b}$ ) was chosen as the proposed consolidation method that would stop the subsidence of the foundations and the cracking of the structure.

Regarding the unauthorized interventions, it was chosen to demolish the masonry wall with RC frame that separates the apse from the rest of the church. The door holes in the lateral walls will be rebuilt to recreate the structural integrity and the authenticity of the church.

The wood framing and covering of the roof will be remade in its entirety if possible using wood elements from what is left of the existing roof $[7,9]$.

\section{DETERMINING THE EFFICIENCY OF THE CONSOLIDATION METHODS}

For the determination of the efficiency of the consolidation methods a third nonlinear analysis was made with the TreMuri program that contain the consolidation methods described above. The analysis was made on the simple model with the church as an independent building $[7,8]$. 
The analysis indicates that on the Ox axis (Figure 20), the shear base force grew to 10800 $\mathrm{KN}$, and the horizontal displacement at the top of the tower went down to $1.60 \mathrm{~cm}$.

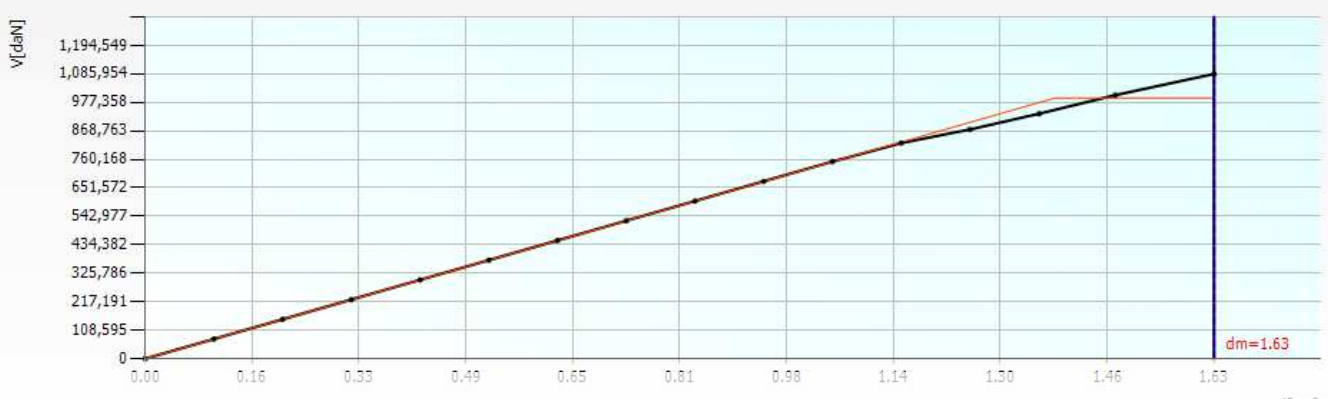

Figure 20: The force-displacement diagram when the seismic force is applied on the Ox axis

On the main façade (Figure $21 \mathrm{a}$ ) observations were made that there is a disappearance of failure mechanisms which remain only in the spandrels. There are a few failure mechanisms left on the spandrels. On the lateral façade (Figure $21 \mathrm{~b}$ ) there are failure mechanisms at the top of the wall and ductile yielding in the spandrels $[7,8]$.

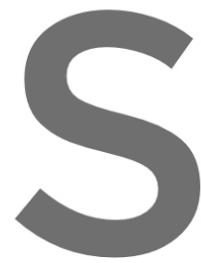

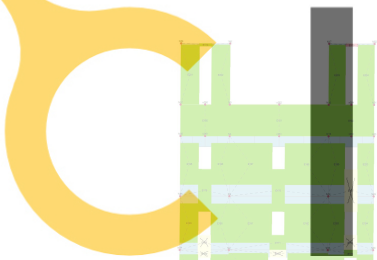

a)

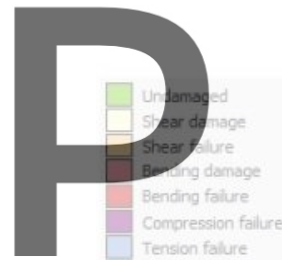

Tension falur

Falive during elastic phase

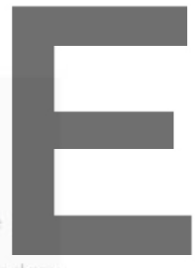

b)

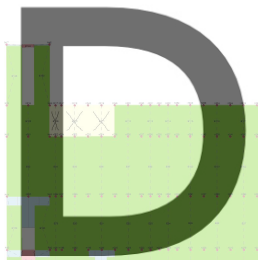

b)
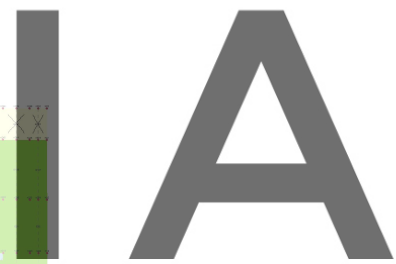

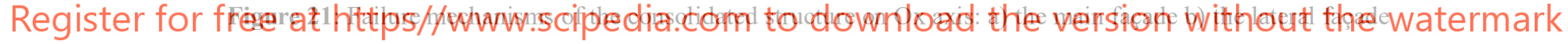

On the Oy axis the force-displacement diagram indicates (Figure 22) an increase of the base shear force to $15000 \mathrm{KN}$ and a reduction of the horizontal displacement of the tower to $4.9 \mathrm{~cm}$.

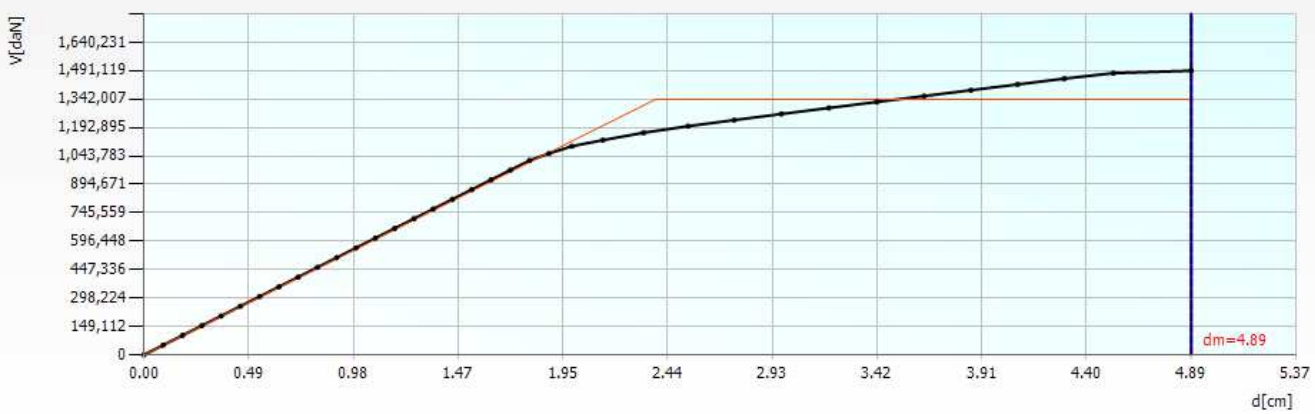

Figure 22: The force-displacement diagram when the seismic force is applied on the Oy axis 
On the main façade of the building (Figure 23 a) there are failure mechanisms only at the spandrels of the tower and on the lateral façade (Figure $23 \mathrm{~b}$ ) multiple failure mechanisms appear along the entire wall.

a)

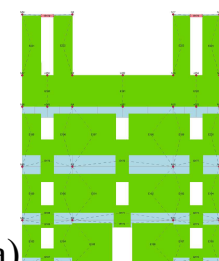

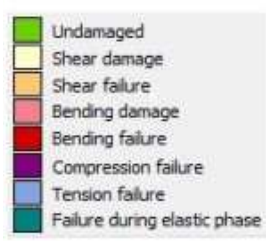

Tension falure
Faliure during elastic phase b)

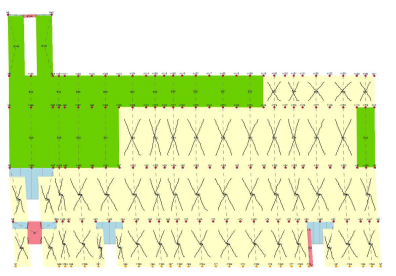

Figure 23: Failure mechanisms of the consolidated structure on Oy axis: a) the main façade, b) the lateral façade

Table 1 represents a comparative study between the results of the non-consolidated structure and the results of the consolidated structure, obtained from TreMuri [7].

Table 1: Comparative table between the results of the non-consolidated and consolidated structure

\begin{tabular}{|c|c|c|c|c|c|c|}
\hline Axis & $\begin{array}{c}\text { Base shear } \\
\text { force before } \\
\text { consolidation } \\
{[\mathrm{KN}]}\end{array}$ & $\begin{array}{c}\text { Base shear } \\
\text { force after } \\
\text { consolidation } \\
{[\mathrm{KN}]}\end{array}$ & $\begin{array}{c}\text { Comparative } \\
\text { growth } \\
\text { between the } \\
\text { base shear } \\
\text { forces } \\
{[\%]}\end{array}$ & $\begin{array}{c}\text { Maximum } \\
\text { displacement } \\
\text { before } \\
\text { consolidation } \\
{[\mathrm{cm}]}\end{array}$ & $\begin{array}{c}\text { Maximum } \\
\text { displacement } \\
\text { after } \\
\text { consolidation } \\
{[\mathrm{cm}]}\end{array}$ & $\begin{array}{c}\text { Comparative } \\
\text { reduction } \\
\text { between the } \\
\text { maximum } \\
\text { displacements } \\
{[\%]}\end{array}$ \\
\hline Transversal $\mathrm{x}$ & 6200 & 10800 & $\mathbf{7 4}$ & 2.00 & 1.60 & $\mathbf{2 0}$ \\
\hline Longitudinal y & 4800 & 15000 & $\mathbf{2 1 3}$ & 5.70 & 4.90 & $\mathbf{1 4}$ \\
\hline
\end{tabular}

Table 2: Comparative table between the vibration modes of the structure

\begin{tabular}{|c|c|c|c|}
\hline & First mode & Second mode & Third mode \\
\hline Before consolidation & $0.518 \mathrm{~s}$ & $0.454 \mathrm{~s}$ & $0.431 \mathrm{~s}$ \\
\hline After consolidation & $0.518 \mathrm{~s}$ & $0.442 \mathrm{~s}$ & $0.422 \mathrm{~s}$ \\
\hline
\end{tabular}

\section{CONCLUSIONS}

The Franciscan Monastery is part of the architectural ensemble of the Fortress of Arad and is nominated in the list of Historical Monuments of national importance. The structural health of the buildings from this architectural ensemble, the understanding and the correct utilization, make possible the social reinsertion in this historically urban site.

This paper represents the first time in Romania that a study of the bearing capacity of a historic baroque style church was done. The studies will continue with on-site testing to figure out the exact properties of the materials used in the construction of the church.

The dynamic analysis utilizes to diagnose the Franciscan Church permitted: the identification of the structural strength before and after the consolidation and the identification of the proposed consolidation solutions used to restore the historic architectural surfaces. 
The first nonlinear analysis in the TreMuri program indicated that the structure may suffer significant structural damage after an earthquake with the ground acceleration of $0.20 \mathrm{~g}$ and requires structural consolidation.

The second nonlinear analysis indicated that the building would have a higher structural resistance if the two adjacent bodies would be taken into consideration in the model.

The structural consolidation was made with modern reversible technologies that do not affect the historical value of the building. The unauthorized interventions made to the structure were eliminated to reestablish the structural resistance and the authenticity of the building.

The third nonlinear analysis indicates that the structural resistance of the consolidated building significantly increased compared to the unconsolidated structure. Also this analysis shows us that the number of structural elements in the consolidated area of the towers that suffer failure modes were reduced.

Acknowledgements: I would like to thank Eng. Rares Bradeanu the representative of Kerakoll Company who helped with information about the technology used in the restoration of historical monuments. And also we would like to thank my colleagues Razvan Dinu and Luiza Rosu for their collaboration.

\section{REFERENCES}

[1] Rosu, L. Estetica Mănăstirii Franciscane din Cetatea Aradului. Dissertation thesis, The Faculty of Architecture and Urban Planning (UPT), Timisoara, Romaina (2018).

[2] Dinu, R. Repertoriul Decorativ al Bisericii Mănăstirii Franciscane din Arad și Propuneri de Restaurare. Dissertation thesis, The Faculty of Architecture and Urban Planning (UPT), Timisoara, Romaina (2018).

[3] Narita, A., Mosoarca, M., Modena, C., da Porto, F., Munari, M., Taffarel, S., Marson, C., Valotto, C. and Roverato, M. Behavior of Historic Buildings in Zones with Moderate Seismic Activity. Case Study: Banat Region, Romania. World Multidisciplinary Civil EngineeringArchitecture-Urban Planning Symposium, Procedia Engineering 161 (2016) 729-737.

[4] Mosoarca, M. and Gioncu, V. Failure Mechanisms for Historical Religious Buildings in Romanian Seismic Areas. Journal of Cultural Heritage 145 (2013) e65-e72.

[5] Valluzzi, M.R. and Modena, C. Current Practice and Open Issues in Strengthening Historical Buildings with Composites. Materials and Structures (2014) 47: 1971-1985.

[6] Modena, C., da Porto, F., Valluzzi, M.R. and Munari, M. Criteria and Technologies for the Structural Repair and Strengthening of Architectural Heritage. Rehabilitation and Restoration of Structures Conference (2013) 51-74.

[7] Ion, A. Soluții Moderne de Analiză Structurală şi Consolidare a Bisericii Franciscane din Cetatea Aradului. Dissertation thesis, The Faculty of Architecture and Urban Planning (UPT), Timisoara, Romaina (2019).

[8] S.T.A. DATA srl. TreMuri User Manual Release 10.9.0. http://www.3muri.com/documenti/brochure/en/3muri10.9.0_eng.pdf(last visit 12.01.2020)

[9] KERAKOLL. Solutii si produse. Http://products.kerakoll.com/catalogo.asp?id_lingua=23\#(last visit 12.01.2020) 